\title{
Arthritic lesions and congenital fusion in foot bones of Panochthus sp. (Xenarthra, Cingulata)
}

\author{
FERNANDO HENRIQUE DE S. BARBOSA ${ }^{1}$, KLEBERSON DE O. PORPINO ${ }^{2}$, BRUCE \\ M. ROTHSCHILD ${ }^{3}$, UIARA G. CABRAL ${ }^{4}$ and LILIAN P. BERGQVIST ${ }^{1}$
}

\begin{abstract}
${ }^{1}$ Programa de Pós-Graduação em Geologia, Departamento de Geologia, Instituto de Geociências, Universidade Federal do Rio de Janeiro, Av. Athos da Silveira Ramos, 274, Cidade Universitária, Ilha do Fundão, 21941-916 Rio de Janeiro, RJ, Brazil

${ }^{2}$ Departamento de Ciências Biológicas, Universidade do Estado do Rio Grande do Norte, Av. Professor Antônio Campos, s/n, Costa e Silva, 59610-090 Mossoró, RN, Brazil

${ }^{3}$ Carnegie Museum of Natural History, 4400 Forbes Ave, 44272, Pittsburgh, Pennsylvania, USA

${ }^{4}$ Setor de Paleovertebrados, Departamento de Geologia e Paleontologia, Museu Nacional/Universidade Federal do Rio de Janeiro, Quinta da Boa Vista, São Cristóvão, 20940-040 Rio de Janeiro, RJ, Brazil
\end{abstract}

Manuscript received on November 21, 2016; accepted for publication on February 24, 2017

\begin{abstract}
How to cite: BARBOSA FHS, PORPINO KO, ROTHSCHILD BM, CABRAL UG AND BERGQVIST LP. 2019. Arthritic lesions and congenital fusion in foot bones of Panochthus sp. (Xenarthra, Cingulata). An Acad Bras Cienc 91: e20160812. DOI 10.1590/0001-3765201720160812.
\end{abstract}

\begin{abstract}
A set of lesions are re-described and new pathological findings in foot bones of Panochthus sp. (Xenarthra, Cingulata) are presented. The material reexamined in fact presents enthesiophytes instead of osteoartrithis, as previously interpreted. Furthermore, Calcium Pyrophosphate Deposition Disease (CPPD) was observed, a lesion absent in previous report. CPPD also was found in another set of foot bones and it was associated with a congenital fusion of two sesamoids. The material studied were collected in two natural tank deposits, one in Paraíba (material reexamined) and other in Rio Grande do Norte (new pathological findings) State.
\end{abstract}

Key words: Arthritis, Congenital Fusion, Glyptodont, Panochthus sp.

\section{INTRODUCTION}

Arthritis is an informal term encompassing more than 100 types of joint diseases with different etiologies. It is one of the three major causes of skeletal lesions found in osseous remains (the other two conditions being trauma and infections; Ortner 2003), and commonly found in the fossil record since Permian (Rothschild et al. 2012).

Correspondence to: Fernando Henrique de Souza Barbosa E-mail: fhsbarbosa@gmail.com ORCid: https://orcid.org/0000-0002-9738-2468

* Contribution to the centenary of the Brazilian Academy of Sciences.
Among xenarthrans - a notable group of endemic mammals of the Neotropical Region (Wetzel 1985) - arthritis has a modest record, including cases of spondyloarthropathy associated with calcium pyrophosphate deposition disease and osteoarthritis in the glyptodonts Glyptotherium sp. (Barbosa et al. 2014b) and Panochthus sp. (Barbosa and Luna 2014). Osteoarthritis also was identified on an axis of the giant ground-sloth Eremotherium larillardi (Barbosa et al. 2014a) and on a metatarsal III and an ectocuneiform assigned to Panochthus sp. (Henriques et al. 1998). Here we describe new cases of arthritic lesions in metatarsal and tarsal bones of 
Panochthus sp. from northeast Brazil, including a reevaluation of the diagnosis proposed for the specimens analyzed by Henriques et al. (1998). In addition, we describe the first case of a congenital anomaly in sesamoids bones in a glyptodont.

The genus Panochthus Burmeister, 1866 (Xenarthra, Cingulata, Gliptodontoideia) is one of the largest and best known genera among glyptodonts (Paula-Couto 1979, Zamorano et al. 2013). At least six valid species, which form a monophyletic group (Zamorano and Brandoni, 2013, Porpino et al. 2014), were assigned to this genus. They are known from the early-middle Pleistocene of Argentina (Zamorano et al. 2014a) to the Pleistocene-Holocene of northeast Brazil (Porpino et al. 2014) and a recent finding suggests that the genus would already be present in the late Pliocene (Zamorano et al. 2014b). They share a suite of remarkable characters, such as a well-developed caudal tube with striated conical tubercles on its sides and the absence of the rosette ornamentation pattern on most carapace osteoderms, typical of most glyptodonts (Zamorano et al. 2014a). Two valid species of this genus are recognized from northeast Brazil (Porpino et al. 2014): Panochthus greslebini Castellanos, 1941 and Panochthus jaguaribenses Moreira, 1965, both diagnosed by caudal tube characters.

\section{MATERIALS AND METHODS}

The specimens here analyzed are housed in the paleontological collections of the Museu Nacional, Universidade Federal do Rio de Janeiro (MN/UFRJ, Rio de Janeiro city, Rio de Janeiro State, Brazil) and Museu Câmara Cascudo, Universidade Federal do Rio Grande do Norte (MCC/UFRN, Natal city, Rio Grande do Norte State, Brazil). The specimens include a left metatarsal III (MN 3631-V), a left ectocuneiform (MN 3734-V), a right ectocuneiform (MCC 1559-V), a right mesocuneiform (MCC
1559-V), a right metatarsal IV (MCC 1559-V) and two sesamoids of metatarsal III (MCC 1559-V).

All material is assigned to Panochthus sp. and was collected in two natural tank deposits - sedimentary deposits occurring in natural depressions developed on basement rock outcrops by physical-chemical weathering, common in northeastern Brazil (Araújo-Júnior et al. 2013). MN/ UFRJ specimens were collected at Campo Alegre site, Taperoá municipality, Paraíba State, Brazil and the MCC/UFRN specimens were collected at Lagoa do Santo site, Currais Novos municipality, Rio Grande do Norte State, Brazil (Fig. 1). The specimens from Campo Alegre site were found in association with two caudal tubes belonging to P. greslebini and P. jaguaribensis but, like most postcranial material found in this site, cannot be confidently assigned to any of these species (see Porpino et al. 2014 for a full explanation). The specimens belonging to MCC/UFRN collection received the same number because they were found articulated and are part of a near complete pes belonging to a single individual (Porpino and Bergqvist 2002).

\section{RESULTS}

In dorsal view, the left metatarsal III (MN 3631-V) has reactive new bone formation near the proximal articular surface of the ectocuneiform, forming a rugous bony spur (Fig. 2b). The same type of bone overgrowth is evident on lateral view, near the articular surface for the left metatarsal IV (Fig. 2c). The left ectocuneiform (MN 3734-V) exhibits the same bone overgrowth on its lateral face (Fig. 3b). Additionally, the left metatarsal III manifests bone formation marginally located and projecting onto the proximal articular surface (ectocuneiform articulation) (Fig. 2d).

The two sesamoids associated with the right metatarsal III (MCC 1559-V) are fused (Fig. 4b). Lateral view of the right mesocuneiform and the 


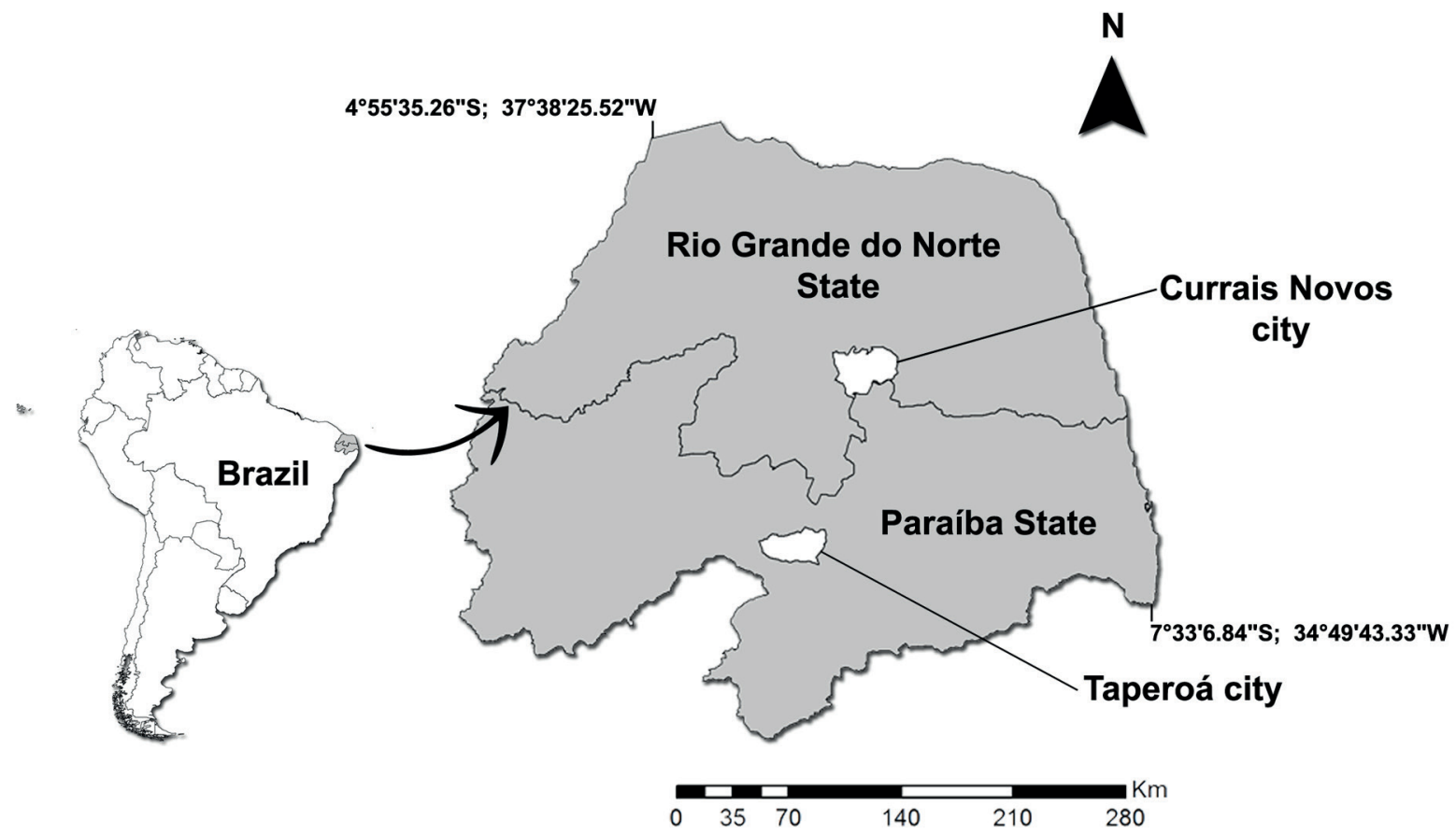

Figure 1 - Location map of the fossil localities (Lagoa do Santo site, Currais Novos municipality, Rio Grande do Norte State and Campo Alegre site, Taperoá municipality, Paraíba State).

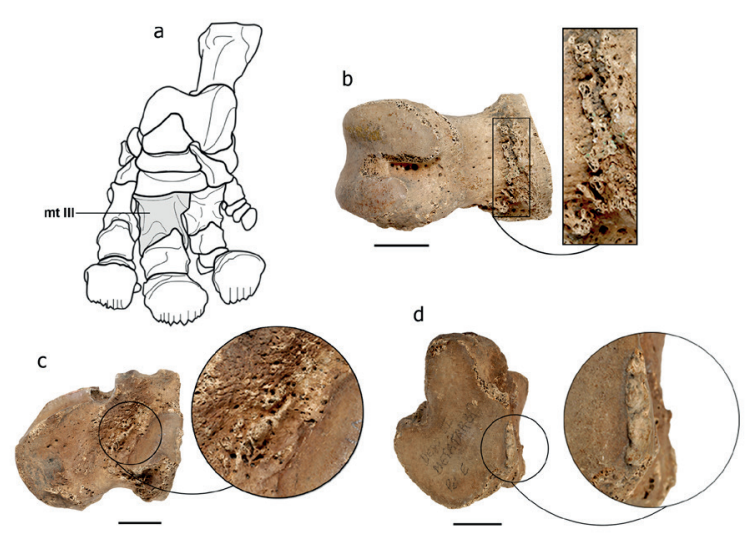

Figure 2 - (a) scheme of the foot of Panochthus sp. (modified from Burmeister, 1874); (b) left metatarsal III (MN 3631-V) in dorsal view with highlight of the lesion; (c) left metatarsal III (MN 3631-V) in lateral view with highlight of the lesion; (d) proximal articulation of left metatarsal III (MN 3631-V) with highlight of the lesion. Scale bar $=2.0 \mathrm{~cm}$. Abbreviation: $\mathrm{mt}$ III: metatarsal III.
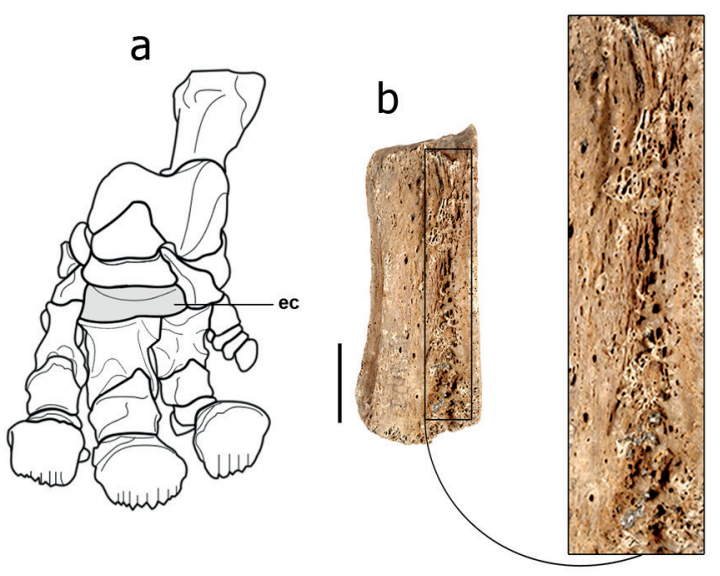

Figure 3 - (a) scheme of the foot of Panochthus sp. (modified from Burmeister, 1874); (b) left ectocuneiform (MN 3734-V) in lateral view with highlight of the lesion. Scale bar $=2.0 \mathrm{~cm}$. Abbreviation: ec: ectocuneiform. 

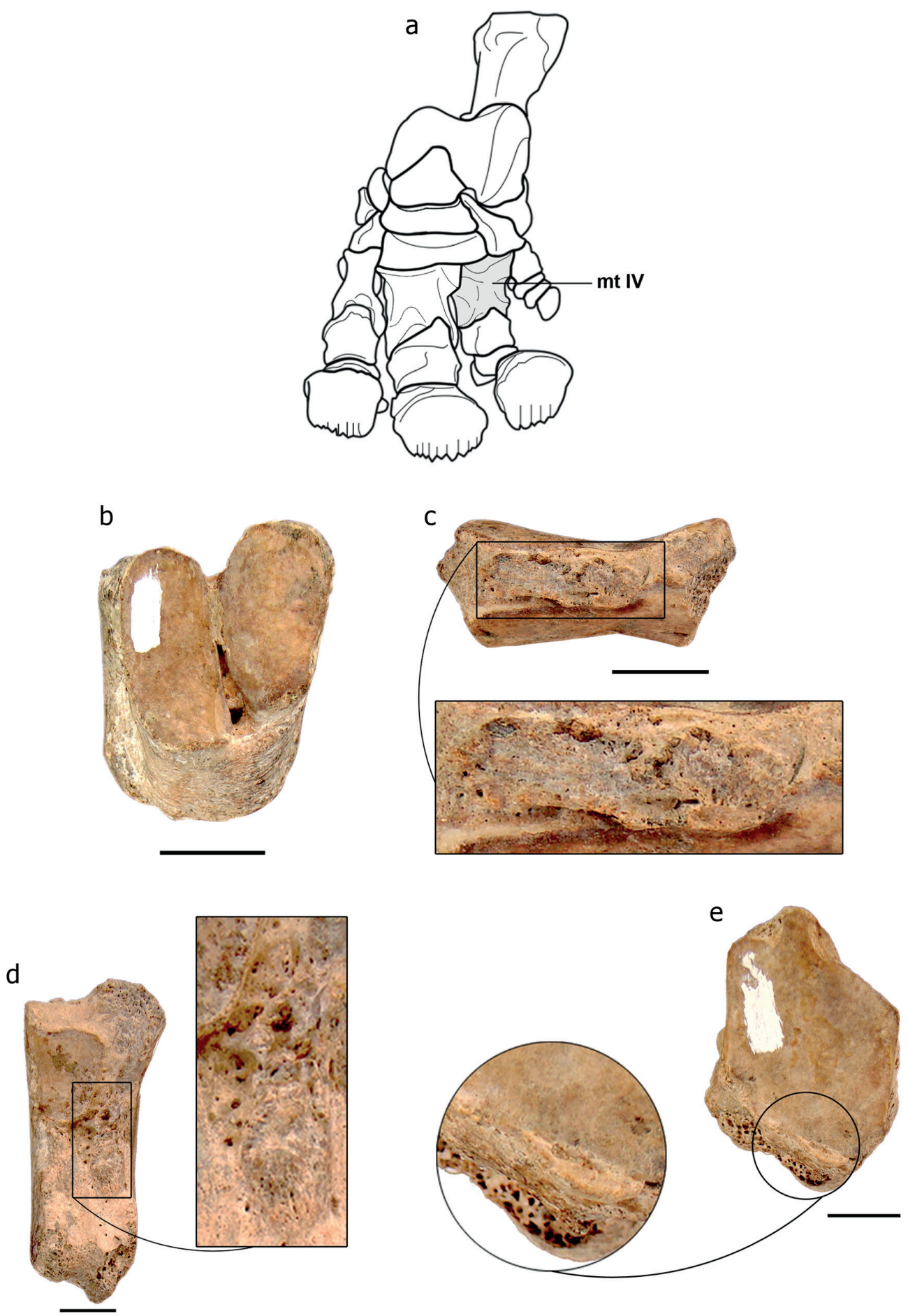

Figure 4 - (a) scheme of the foot of Panochthus sp. (modified from Burmeister, 1874); (b) right sesamoids (MCC 1559-V) associated with metatarsal III fused; (c) right mesocuneiform in lateral view with highlight of the lesion; (d) right sesamoid (MCC 1559-V) associated with metatarsal II in lateral view with highlight of the lesion; (e) proximal articulation of the metatarsal IV (MCC 1559-V) with highlight of the lesion. Scale bar $=2.0 \mathrm{~cm}$. Abbreviation: $\mathrm{mt}$ IV: metatarsal IV. 
sesamoid associated with the right metatarsal II reveal an extensive reactive new bone formation similar to that observed in MN 3631-V and MN 3734-V (Fig. 4c-d). Metatarsal IV (MCC 1559-V) exhibits new bone formation projecting onto the proximal joint surface of the entocuneiform (Fig. $4 \mathrm{e})$. This lesion is identical in appearance to that recognized in the left metatarsal III (MN 3631-V).

\section{DIFFERENTIAL DIAGNOSIS}

The lesions in the left metatarsal III (MN 3631$\mathrm{V})$ and left ectocuneiform (MN 3734-V) were originally interpreted as osteophytes (Henriques et al. 1998; figures 1-4), i.e., bone overgrowth on marginal edges of the synovial joint surface (Ortner 2003), which is considered the diagnostic indicator of osteoarthritis (Rothschild and Martin 2006). However, reexamination of the material revealed that these bone alterations are not actually located on the marginal edges of the synovial articular surfaces. Therefore, they cannot be considered osteophytes and are not indicative of osteoarthritis. In fact, the bone overgrowth observed in both specimens represent enthesiophytes, that is, bone reaction at the sites of attachment of tendons, ligaments or capsule insertion (Jacobs 1983, Rothschild and Martin 2006). Enthesitis was in the past considered suggestive of spondyloarthropathy (Rothschild 1982, Resnick 2002). However, it is frequently observed in healthy individuals (human population). When occurring in isolation it cannot be considered a diagnostic criterion for spondyloarthropathy (Rothschild 2013). Enthesitis was noted in the right mesocuneiform and the sesamoid associated with the right metatarsal II recovered from the Lagoa do Santo site. As for the aforementioned specimens, these alterations cannot be attributed to spondyloarthropathy due to the lack of additional evidence (e.g. subcondral erosions, syndesmophyte; Rothschild 2013).
Interestingly, metatarsal III (MN 3631-V) presents new bone formation projecting onto the joint surface, a critical observation lacking in the report by Henriques et al. (1998; Fig. 2d). It is also observed in metatarsal IV (MCC 1559-V). Such new bone formations are actually calcific sheets, which are diagnostic of calcium pyrophosphate deposition disease (CPPD; Rothschild 1982, Markel and Hart 1982, Resnick 2002), a variety of crystalline arthritis (Rothschild 1982, Resnick 2002). Although the calcific sheets are marginally located, they differ from osteophytes because they are projected onto the articular surface instead of being parallel to it.

Among the types of arthritis, spondyloarthropathy is the most common in the fossil record (Rothschild and Martin 2006), while CPPD and osteoarthritis are rare in free-raging animals. However, Pleistocene Xenarthra, especially cingulates, has presented a different story so far. The association of CPPD with other types of arthritis in fossil xenarthrans (Barbosa et al. 2014b, Barbosa and Luna 2014), suggests that it was not as rare as in recent animals, at least in this group. Nevertheless, new investigations are necessary to evaluate the prevalence of this and other kinds of arthritic lesions within this group, as well as their potential causes.

The merging of the sesamoids of the metatarsal III into a single piece (Fig. 4b) likely represents an abnormal fusion. This type of fusion is commonly congenital and results from an abnormal differentiation and segmentation of primitive mesenchyme (Jack 1954). Abnormal fusion of foot bones is well known in humans (e.g. De Villiers Minnaar 1952, Jack 1954, Newman and Newberg 2000), but, until now, unknown in the mammalian fossil record of South America. 


\section{ACKNOWLEDGMENTS}

This study was funded by the Conselho Nacional de Desenvolvimento Científico e Tecnológico (CNPq) (grants 159733/2013-8, FHSB; 308013/2015-8, KOP; 307405/2012-5, LPB). We thank Deise D. R. Henriques (Museu Nacional/UFRJ) and Maria de Fátima C. F. dos Santos (Museu Câmara Cascudo/ UFRN) for the access to specimens studied here. We also would like thank the two anonymous reviewers and associate editor for their valuable comments.

\section{REFERENCES}

ARAÚJO-JÚNIOR HI, PORPINO KO, XIMENES CL AND BERGQVIST LP. 2013. Unveiling the taphnomy of elusive natural tank deposits: A study case in the Pleistocene of northeastern Brazil. Palaeogeog Paleoecol 378: 52-74.

BARBOSA FHS, ARAÚJO-JÚNIOR HI AND OLIVEIRA EV. 2014a. Neck osteoarthritis in Eremotherium laurillardi (Lund, 1842; Mammalia, Xenarthra) from the Late Pleistocene of Brazil. Int J Paleopathol 6: 60-63.

BARBOSA FHS AND LUNA C. 2014. Lesiones en la coraza y endoesqueleto de un ejemplar de Panochthus Burmeister, 1866 (Mammalia, Glyptodontia) de la Provincia de Córdoba, Argentina. Rev Mus Prov Ciênc Nat/“Dr. Arturo Umberto Illia" 1: 9-26.

BARBOSA FHS, PORPINO KO, FRAGOSO AB AND OLIVEIRA EV. 2014b. Arthritis in a glyptodont (Mammalia, Xenarthra, Cingulata). Plos One 9(2): e88646.

DE VILLIERS MINNAAR AB. 1952. Congenital fusion of the lunate and triquetal bones in the South Africa Bantu. J Bone Joint Surg 34b: 45-48.

HENRIQUES DDR, SOARES AA AND MELLO MGS. 1998. Registros de reação óssea em Panochthus BURMEISTER, 1866 do Pleistoceno do Estado da Paraíba. Acta Geol Leopold XXI (46/47): 149-155.

JACK EA. 1954. Bone anomalies of the tarsus in relation to "peroneal spastic flat foot". J Bone Joint Surg 36B: 530542.

JACOBS JC. 1983. Spondyloarthritis and enthesopathy: Current concepts in Rheumatology. Arch Intern Med 143: 103-107.

MARKEL SF AND HART WR. 1982. Arthropathy in calcium pyrophosphate dihdratecrystal deposition disease. Arch Pathol 106: 529-533.

NEWMAN JS AND NEWBERG AH. 2000. Congenital tarsal coalition: multimodality evaluation with emphasis on CT and MR imaging. Radiographics 20: 321-332.
ORTNER DJ. 2003. Osteoarthritis and Diffuse Idiophatic Skeletal Hyperostosis. In: IDENTIFICATION PATHOLOGICAL CONDITIONS IN HUMAN SKELETAL REMAINS, Academic Press, San Diego: D.J. (Ed), Ortner, p. 545-560.

PAULA-COUTO C. 1979. Tratato de Paleomastozoologia, Rio de Janeiro: Academia Brasileira de Ciências, 590 p.

PORPINO KO AND BERGQVIST LP. 2002. Novos achados de Panochthus (Mammalia, Cingulata, Glyptodontoidea) no Nordeste do Brasil. Rev Bras Paleontol 4: 51-62.

PORPINO KO, FERNICOLA JC, CRUZ LE AND BERGQVIST LP. 2014. The intertropical Brazilian species of Panochthus (Xenarthra, Cingulata, Glyptodontoidea): a reappraisal of their taxonomy and phylogenetic affinities. J Vertebr Paleontol 34: 1165-1179.

RESNICK D. 2002. Diagnosis of Bone and Joint Disorders. Saunders, Philadelphia.

ROTHSCHILD BM. 1982. Rheumatology: A Primary Care Approach. New York: York Medical Press, 416 p.

ROTHSCHILD BM. 2013. Universal nature of spondyloarthropathy as a reactive disease, reflecting differential sensitivities. Curr Rheumathol Rev 9: 81-89.

ROTHSCHILD BM AND MARTIN LD. 2006. Skeletal impact of disease. Albuquerque: New Mexico Museum of Natural History \& Science, Division of the Department of cultural affairs, Bulletin 33, $226 \mathrm{p}$.

ROTHSCHILD BM, SCHULTZE HP AND PELLEGRINI R. 2012. Herpetological Osteopathology: Annotated Bibliography of Amphibians and Reptiles. New York: Springer, $450 \mathrm{p}$.

WETZEL R. 1985. The identification and distribution of recent Xenarthra (= Edentata). In: THE ECOLOGY AND EVOLUTION OF ARMADILLOS, SLOTHS, AND VERMILINGUAS. Washington, D.C. G.G. Montgomery: Smithsonian Institution Press, p. 5-21.

ZAMORANO M AND BRANDONI D. 2013. Phylogenetic analysis of the Panochthini (Xenarthra, Glyptodontidae), with remarks on their temporal distribution. Alcheringa 37: 442-451.

ZAMORANO M, SCILLATO-YANE GJ AND ZURITA AE. 2013. An enigmatic and large-sized specimen of Panochthus (Glyptodontidae, "Panochthini") from the Ensenadan (early-middle Pleistocene) of the Pampean region, Argentina. Rev Mex Biod 84: 847-854.

ZAMORANO M, SCILLATO-YANÉ GJ AND ZURITA AE. 2014a. Revisión del género Panochthus (Xenarthra, Glyptodontidae). Rev Mus La Plata 14: 1-46.

ZAMORANO M, TAGLIORETTI M, ZURITA AE, SCILLATO-YANÉ GJ AND SCAGLIA YF. 2014b. El registro más antiguo de Panochthus (Xenarthra, Glyptodontidae). Estud Geol 70(1): 004. 